\title{
PERANAN CORPORATE STRATEGY DALAM KESUKSESAN-KEGAGALAN MERGER \& AKUISISI: SUATU TELAAH LITERATUR
}

\author{
Andreas Lako \\ Unika Soegijapranata Semarang
}

\begin{abstract}
Most empirical studies and literature reviews documented that the final results of the wave of mergers and acquisitions in the United States, Canada, and European countries during the decade of 1980s, 1990s and 2000s were always dissatisfactory. In fact, the extent of the failure is higher than the success.

However, a comprehensive investigation on the factors motivating the rise of mergers and acquisitions and the causes for success and failure is still rare. This paper reviews the contribution of corporate strategy in success and failure of mergers and acquisitions during three decades. Specifically, this paper reviews literatures with respect to the motives of corporate mergers and acquisitions actions and the trigger factors of their failures.

The result of the literature review shows that corporate strategy has a significant contribution to the extent of the success and failure of corporate mergers and acquisitions. The review finds that trigger factors of mergers and acquisitions failure are the ambiguous communications and cross-cultural gaps, inappropriate and insufficient integration and transformation of new corporate culture, incompatible leadership style accustomed with a new corporate climate, inappropriate corporate planning and internal consolidation, inappropriate anatomy of organizational internal factors, and erroneousness in choosing the partners and the timing of mergers and acquisitions. To ensure the successful and sustainability of corporate mergers and acquisitions, therefore, top management and task force of mergers and acquisitions need to accurately consider those internal and external organization factors.
\end{abstract}

Keywords: merger and acquisition, corporate strategy, cross-cultural, financing and operating sinergy, stockholder wealth.

\section{PENDAHULUAN}

Pada awal dekade 1980an hingga awal 2000an, merger dan akuisisi (M\&A) menjadi pilihan utama dalam corporate strategy oleh para CEO (chief executive officers) dan pemegang saham korporat di Amerika Serikat, Canada dan Eropa karena strategi diversifikasi-konglomerasi yang digunakan selama era 1950an-1960an, dan strategi portfolio planning yang diterapkan selama era 1970an tidak mampu memberi kontribusi yang signifikan terhadap peningkatan the value of the firms dan stakeholders wealth (Goolds \& Luchs 1997; Shleifer \& Vishny 1994; Hill 1994; Johnson 1995). Selama periode tersebut, tren merger \& akuisisi juga terjadi pada sejumlah korporat di Indonesia.

Namun, hasil-hasil evaluasi kritis dan riset empiris yang dilakukan sejumlah periset selama dekade tersebut menunjukkan bahwa tingkat kegagalan merger \& akuisisi jauh lebih besar daripada tingkat kesuksesannya (Goolds \& Luchs 1997; Kwansa 1994; Johnson 1995; Post et al. 1996; Sorell \& Richardson 1999; Appelbaum et al., 2000; Hoare \& Cartwright 1997). Sejauh yang 
penulis telusuri, investigasi secara komprehensif terhadap sumber-sumber pemicu kesuksesankegagalan merger \& akuisisi tersebut masih sangat sedikit atau lebih bersifat parsial.

Tulisan ini merupakan hasil literature review yang menginvestigasi peran corporate strategy dalam kesuksesan-kegagalan merger \& akuisisi di Amerika, Canada dan Eropa pada era 1980an - 2000an. Secara khusus, bagian kedua tulisan ini membahas esensi dan motif dilakukannya merger \& akuisisi. Bagian ketiga membahas sumber-sumber pemicu kesuksesankegagalan merger \& akuisisi. Bagian keempat membahas desain organisasional (corporate strategy) yang perlu dipertimbangan tim task force merger \& akuisisi dan manajemen (CEO) dalam mendorong kesuksesan pelaksanaan merger \& akuisisi korporat.

\section{ESENSI DAN MOTIF MERGER \& AKUISISI}

Secara konseptual, merger dan akuisisi yang merupakan salah satu bentuk restrukturisasi korporat memiliki makna berbeda. Merger merupakan suatu kombinasi dari dua atau lebih korporat dimana hanya satu korporat tetap survive dengan namanya sementara korporat lain hilang eksistensinya sebagai suatu entitas legal (Foster 1986; Gaughan 1999). Sementara akuisisi adalah pembelian seluruh atau sebagian kepemilikan saham atau aset suatu korporat oleh korporat lain (Foster 1986). Namun dalam kebanyakan literatur, istilah merger dan akuisisi sering digunakan secara bersama-sama sebagai satu-kesatuan. Karena itu, tulisan ini juga menggunakan istilah merger \& akuisisi sebagai satu-kesatuan.

Secara umum, ada dua tujuan utama perusahaan melakukan merger \& akuisisi yaitu: 1) untuk meningkatkan nilai pasar ekuitas yang dimiliki oleh para pemegang saham yang ada, dan 2) untuk meningkatkan kesejahteraan manajemen yang ada dan nilai perusahaan (Foster 1986; Bieshaar et al. 2001; Goldberg \& Godwin 2001). Stewart III et al. (2001) menyatakan bahwa "motif" utama dalam restrukturisasi perusahaan adalah memperkuat insentif, mencapai suatu business fit yang lebih baik, mempertajam fokus manajemen, menciptakan pure plays yang memiliki investasi unik dan menarik, membatasi suatu investasi yang tidak produktif terhadap cash flow, mengurangi subsidi untuk bisnis-bisnis yang underperforming, mencapai suatu pemakaian yang dinilai lebih tinggi untuk aset-aset, meningkatkan debt capacity, dan menghemat pajak.

Gaughan (1999) mengidentifikasi ada sejumlah motif dilakukannya merger \& akuisisi, yaitu: (1) motif untuk pertumbuhan (growth) internal dan eksternal bisnis; (2) motif untuk sinergi bisnis berupa operating sinergy berupa economies of scale dan economies of scope yang secara ekonomis dapat meningkatkan penerimaan dan mengurangi kos; dan financing sinergy yaitu merujuk pada dampak merger \& akuisisi terhadap cost of capital untuk partner merger atau pengakuisisi; (3) motif ekonomi yaitu untuk meningkatkan market share dan market power perusahaan terhadap pesaing, dan memperkuat buyer-seller relationship; (4) motif tax benefits yaitu untuk mendapatkan tax benefits; dan (5) motif untuk memperbaiki atau meningkatkan efektivitas manajerial.

Sejumlah riset empiris juga menemukan bahwa para CEO melakukan merger \& akuisisi karena didorong oleh sejumlah motif. Baket et al. (1983) menemukan bahwa motif CEO melakukan merger \& akuisisi adalah 1) untuk mempengaruhi pertumbuhan yang lebih tinggi; 2) untuk memperoleh economies of scale; 3) untuk meningkatkan pangsa pasar; 4) untuk memperluas line bisnis secara geografis; 5) untuk meningkatkan nilai pasar saham; 6) untuk memperluas atau memperbaiki product mix; dan 7) untuk meningkatkan power dan prestisius perusahaan.

Sementara Hackett (1996) mengidentifikasi ada empat manfaat merger (rumah sakit) yaitu: 1) pengurangan dalam kos perusahaan dapat terjadi untuk tingkat yang signifikan melalui economies of scale dalam management overheads yang mencapai 2-6 persen dari operating income; 2) jumlah pelayanan kritis yang lebih besar dapat menciptakan suatu sumber penawaran dan permintaan yang stabil dan nyaman untuk jasa-jasa departemen individual; 3) integrasi terhadap semua central proses untuk core business dapat memberikan kesuksesan jika perusahaan membangun relasi yang erat dalam konteks value-chain approach seperti diusulkan 
Porter (1985); dan 4) merger dapat mengurangi tekanan persaingan karena semakin besarnya konsentrasi pasar yang memungkinkan perusahaan menaikkan harga untuk para konsumen atau menolak reduksi harga.

Berkenaan dengan fokus dari merger \& akuisisi pada era 1980an, Goold dan Luchs (1997) mengindentifikasi ada sejumlah usaha yang dilakukan dalam merger \& akuisisi. Pertama, cost cutting at headquater yaitu melakukan pemotongan kos pada cabang-cabang perusahaan yang tidak memberikan kontribusi tinggi. Kedua, value-based planning yaitu melakukan perencanaan yang berbasis pada nilai pemegang saham, nilai pasar perusahaan, dan strategi bersaing. Ketiga, melakukan stick to the kitting, yaitu konsep kesuksesan perusahaan berdasarkan core business sehingga mendorong perusahaan menspesialisasikan dalam industri tertentu dan memfokuskan pada perbaikan pengetahuan dan keahlian mereka pada area-area yang paling mereka kenal. Keempat, corporate restructuring baik secara paksa maupun sukarela, dimana korporat membatasi bisnis hanya untuk satu atau beberapa bisnis dalam industri yang paling terkait. Perusahaan mendivestasikan unit-unit bisnis yang tidak memberikan value added dan mempertahankan core business atau core portfolio yang memberikan kontribusi besar untuk perbaikan kinerja korporat dalam jangka panjang.

Sementara untuk dekade 1990an dan 2000an, Goold dan Luchs (1997) dan Bieashaar et al. (2001) mengidentifikasi ada sejumlah usaha yang dilakukan yaitu: 1) membatasi diversifikasi bisnis hanya pada bisnis-bisnis yang bersinergi tinggi; 2) memfokuskan pada eksploitasi core competences antar bisnis yang berbeda; dan 3) melakukan pembentukan portfolio bisnis yang fit dengan "dominant logic" manajerial dan gaya kepemimpinan CEO.

\section{PEMICU KESUKSESAN-KEGAGALAN MERGER \& AKUISISI}

Meskipun dorongan untuk melakukan merger \& akuisisi dipengaruhi oleh sejumlah motif, baik yang terungkap maupun tidak terungkap (unspoken motives) secara eksplisit, namun hasilhasil dari sejumlah riset empiris menunjukkan bahwa pelaksanaan merger \& akuisisi tidak selalu memberikan hasil akhir yang mengembirakan. Secara keseluruhan, hasil-hasil analisis dan riset empiris yang menguji tingkat kesuksesan-kegagalan merger\&akuisisi dalam tiga dasawarsa terakhir memberikan dua kesimpulan berbeda.

Dari perspektif manfaat merger \& akuisisi untuk meningkatkan kesejahteraan CEO dan pemegang saham (shareholders wealth), sejumlah studi empiris memberikan bukti bahwa para pemegang saham dari perusahaan-perusahaan pengakuisisi atau merger menikmati benefits berupa kenaikan harga-harga saham ketika merger \& akuisisi dilakukan (Asquith 1983; Morck et al. 1990; Kwansa 1994; Gaughan 1999; Bieshaar et al. 2001). Bradley et al. (1983) menemukan bahwa penawaran tender merger \& akuisisi dapat menghasilkan gains untuk para pemegang saham target firm. Varaiya (1989) yang menguji relasi antara bid premium dengan nilai-nilai pasar yang dikombinasikan terhadap bidder dan target menemukan bahwa premium yang dibayarkan oleh para bidder terlalu tinggi berkaitan dengan nilai dari target firm untuk pengakuisisi.

Studi-studi terakhir juga memperkuat bukti-bukti empiris sebelumnya. Dengan menggunakan sampel dari 106 perusahaan akuisisi besar, Hayward dan Hambrick (1995) menemukan bahwa para CEO hubris (menggunakan hubris hypothesis) secara positif berhubungan dengan size dari premium yang dibayarkan. Chatterjee \& Lubatkin (1990) menemukan merger korporat dapat menurunkan systematic risks secara signifikan dari related mergers daripada unrelated mergers.

Nail et al. (2001) yang menguji pengaruh dari stock-SWAP merger terhadap shareholder wealth dan bondholder wealth dengan menggunakan 260 sampel merger stock-SWAP selama periode 1963-1996 menemukan bahwa kunci untuk menjelaskan distribusi dari net wealth gains atau losses yang dihasilkan dalam sejumlah merger adalah tingkat kesamaan atau "relatedness" antara penggabungan bisnis perusahaan. Merger dan akuisisi terhadap perusahaan-perusahaan yang 'related" cenderung menghasilkan peningkatan wealth yang signifikan-tidak hanya untuk 
semua securityholders sebagai suatu grup, tapi juga untuk para pemegang saham perusahaan pengakuisisi, dan peristiwa untuk para pemegang obligasi. Sebaliknya, conglomerate mergers cenderung hanya menambah sedikit nilai untuk securityholders sebagai suatu grup, dan tampak menjadi suatu cara yang dapat handal terhadap pengurangan nilai dari saham-saham perusahaan yang mengakuisisi.

Namun dari perspektif manfaat merger \& akuisisi untuk peningkatan kinerja ekonomi korporat, peningkatan tingkat kesejahteraan manajemen dan karyawan, dan pertumbuhan bisnis korporat secara berkenjutan, sejumlah hasil riset empiris memberikan bukti yang mengejutkan, yaitu bahwa tingkat kegagalan merger \& akuisisi jauh lebih besar daripada tingkat kesuksesannya (Kwansa 1994; Johnson 1995; Post et al. 1996; Sorell \& Richardson 1999; Appelbaum et al., 2000; Hoare \& Cartwright 1997; Marks 1999; Totembaum 1999).

Hasil analisis Frank (1990) terhadap sejumlah merger perusahaan-perusahaan multinasional di Eropa mengestimasikan bahwa berkisar $50 \%-70 \%$ dari seluruh merger berakhir dengan kegagalan dikarenakan ketidakcukupan dalam persiapan dan pelatihan. Menurut hasil analisis McKinsey (1996), seperti dikutip Lako (1997a, 1998a), menunjukkan bahwa dari 56 proyek merger \& akuisisi di AS, hanya $23 \%$ proyek merger \& akuisisi yang berhasil mencapai tujuannya, $70 \%$ mengalami kegagalan, dan $7 \%$ tidak jelas arahnya. Evaluasi yang dilakukan Johnson (1995) terhadap sejumlah proyek merger \& akuisisi dalam sektor perbankan di AS dan Inggris menunjukkan bahwa hampir $62 \%$ proyek merger \& akuisisi di kedua negara tersebut gagal mencapai tujuannya karena tingginya opportunity costs. Sementara riset-riset terakhir (Marks 1999; Totembaun 1999) mengindikasikan bahwa merger \& akuisisi memiliki dampak negatif terhadap pada kinerja ekonomi dari entitas baru.

Kegagalan strategi merger \& akuisisi tersebut diakibatkan oleh timbulnya sejumlah masalah yang sangat kompleks. Secara umum, masalah-masalah tersebut dapat dikelompokkan menjadi: 1) adanya ambigiu dalam komunikasi cross-kultural (Rinberg (1997); 2) pengelolaan terhadap integrasi kultural dan proses perubahan kultural yang tidak tepat (Bijlsma-Frankema 2001); 3) gaya kepemimpinan baru yang tidak kondisif dan transformasional (Covin et al. 1997); 4) ketidakcukupan persiapan dan pelatihan terhadap karyawan yang berbeda kultural (Harper \& Cormeraie 1995); 5), ketidaktepatan dalam menganatomi perilaku dari faktor-faktor organisasional dan processes throughout sebelum dan sesudah merger \& akuisisi (Appelbaum et al., 2000; Hoare \& Cartwright 1997); dan 6) pemilihan timing dan partner yang tidak tepat (Johnson 1995).

Secara khusus, pemicu tingginya tingkat kegagalan merger \& akuisisi tersebut dapat dielaborasi lebih lanjut sebagai berikut. Hazel (1995) yang secara khusus menyoroti merger \& akuisisi dalam sektor perbankan mengidentifikasi ada tiga penyebab utama kegagalan. Pertama, pemilihan waktu (timing) pelaksanaan merger \& akuisisi yang kurang tepat sehingga menimbulkan masalah-masalah keuangan dan manajerial yang kompleks. Kedua, pemilihan partner atau mitra merger \& akuisisi yang tidak cocok sehingga mengakibatkan timbulnya perselisihan pendapat yang sulit diselaraskan, perpecahan yang berakhir dengan perceraian, dan sulit diperoleh sinergi kemitraannya. Ketiga, gagal dalam melakukan persiapan, pendekatan dan konsolidasi internal sehingga landasan hidup bersama mereka sangat rapuh dan tidak adaptif dalam menghadapi dinamika perubahan lingkungan.

Pendapat Hazel tersebut diperkuat oleh Post et al. (1996) yang menyatakan bahwa merger \& akuisisi apabila tidak direncanakan secara cermat dan matang pada akhirnya akan mengakibatkan perpecahan dalam tubuh korporat yang digabungkan. Menurut Post et al. (1996) merger \& akuisisi selain dapat memberikan stimuli yang dinamis, menghasilkan gains untuk pemegang saham dan meningkatkan efisiensi ekonomik, juga dapat menimbulkan ekses-ekses negatif seperti mahal secara ekonomik dan merugikan kepentingan stakeholders internal seperti dilakukannya rasionalisasi karyawan.

Adams \& Neely (2000) mengindetifikasi ada sejumlah sumber kegagalan merger \& akuisisi era tahun 1990an dan 2000an yaitu 1) lemahnya konsep-konsep strategik yang dirancang dan 
dimplementasikan dalam proses merger \& akuisisi; 2) adanya masalah-masalah personalitas pada level top manajemen; 3) perbedaan-perbedaan kultural yang tidak mampu diintegrasikan; 4) miskinnya moral karyawan; 5) tidak kompatibelnya information systems; dan lainnya. Hal-hal tersebut menyebabkan kegagalan dalam melakukan integrasi dua atau lebih entitas korporat pasca merger \& akuisisi secara efektif.

Menurut Appelbaum et al. (2000) yang menganalisis perilaku dari faktor-faktor organisasional dan proses pemikiran sebelum, selama dan sesudah merger \& akuisisi, rendahnya tingkat kesuksesan dan miskinnya hasil-hasil dari merger \& akuisisi terhadap kinerja ekonomi disebabkan oleh miskinnya perencanaan sumberdaya manusia (SDM). Ada empat faktor keperilakuan yang menyebabkan kegagalan tersebut yaitu 1) lemahnya media dan proses komunikasi antar pimpinan dan karyawan, 2) lemahnya adopsi dan tidak terinternalisasinya terhadap budaya perusahaan yang baru, 3) proses perubahan organisasi yang cepat sehingga timbul rasa helplessness, kehilangan kontrol terhadap situasi dan masalah-masalah psikologis, dan 4) faktor stres para karyawan selama merger \& akuisisi.

Hasil analisis dari sejumlah riset empiris berkenaan dengan arti penting komunikasi dan integrasi kultural juga menguatkan hasil identifikasi Appelbaum et al. (2000) tersebut. Gopinath \& Becker (2000) menemukan bahwa komunikasi meningkatkan persepsi keadilan karyawan dalam situasi disvestasi dan lay off, dan bahwa komunikasi dan persepsi keadilan yang dicapai tersebut dapat meningkatkan komitmen tapi bukan trust. Risberg (1997) yang menganalisis ambigiutas dan komunikasi dalam akuisisi cross-cultural menyatakan bahwa komunikasi dalam proses akuisisi dapat menghasilkan dan menegosiasikan beberapa meaning out dari sejumlah ambigiutas dan perbedaan kultural antar pihak dalam merger \& akuisisi. Sementara Whalen (2000) menyimpulkan bahwa komunikasi strategik adalah sangat penting untuk kesuksesan implementasi merger \& akuisisi dan dalam integrasi terhadap para karyawan yang diakuisisi ke dalam budaya korporat yang baru. Konflik budaya adalah penyebab utama kegagalan merger \& akuisisi, dan lemahnya komunikasi merupakan penyebab utama dari konflit tersebut.

Faktor leadership style juga berpengaruh besar terhadap sukses-gagalnya merger \& akuisisi. Covin et al. (1997) menginvetigasi apakah gaya kepemimpinan tertentu dapat menjamin bahwa para karyawan puas dengan pekerjaan mereka dan prospek karir pekerjaan setelah merger. Selain itu, mereka juga mempertanyakan apakah ada satu gaya kepemimpinan tertentu yang dapat menjadi prediktif terhadap kesuksesan merger. Hasilnya menunjukkan bahwa power yang berasal dari expert atau referent power berasosiasi dengan kepuasan karyawan dengan suatu merger; sementara sumber lain memiliki sedikit pengaruh atau berpengaruh negatif. Studi ini menyimpulkan bahwa perilaku yang berasosiasi dengan transformational leadership memiliki dampak yang sangat besar terhadap kepuasan karyawan. Gaya kepemimipinan sangat penting untuk kesuksesan suatu merger dan seorang pemimpin membutuhkan pelatihan untuk gaya kepemimpinan yang tepat untuk diadopsi.

Sementara studi yang dilakukan Krug dan Hegarty (2001) menguji bagaimana perspesi para eksekutif terhadap peritiwa-peristiwa merger untuk menentukan apakah mereka tetap bertahan (stay) atau keluar (leave) pasca merger \& akuisisi dengan menggunakan 130 perusahaan AS yang diakuisisi oleh perusahaan multinasional dan 70 perusahaan yang diakuisisi oleh perusahaan AS sendiri selama periode 1986-1989. Hasilnya mengindikasikan bahwa persepsi para eksekutif terhadap pengumuman-pengumuman merger, interaksi dengan para manajer puncak perusahaan pengakuisisi, setelah merger, dan pengaruh jangka panjang dari merger secara signifikan mempengaruhi keputusan mereka untuk tetap bertahan atau meninggalkan perusahaan. Selain itu, studi ini juga membukukan bahwa persepsi yang muncul ketika perusahaan target diakusisi oleh perusahaan multinasional asing akan cenderung mendorong para eksekutif untuk keluar.

Selain faktor-faktor di atas, kesulitan dan ketidakcocokan dalam integrasi atau transfer teknologi dapat menyebabkan terjadinya kegagalan merger \& akuisisi. Bruno (1997) 
mengidentifikasi bahwa teknologi sebagai sumber keunggulan kompetitif dapat dikonseptualisasi sebagai pergerakan (movement) karyawan, kapabilitas dan pengetahuan yang terintegrasi dalam suatu merger \& akuisisi. Untuk kesulitan-kesulitan internal tipikal yang berhubungan transfer teknologi, proses merger \& akuisisi itu sendiri penuh dengan ketidakpastian, stres, dan ketegangan tinggi yang sering menyumbangkan kegagalan untuk memenuhi tujuan strategik, finansial dan operasional korporat yang diindikasikan dalam kombinasi studi kelayakan sebelumnya.

\section{DESAIN CORPORATE STRATEGY UNTUK KEBERHASILAN MERGER \& AKUISISI}

Dari uraian pada bagian ketiga di atas, tampak bahwa faktor-faktor pemicu kesuksesankegagalan merger \& akuisisi dapat berasal dari faktor internal dan eksternal korporat. Faktor internal mencakup perencanaan corporate strategy terhadap entitas baru yang tidak matang, faktor keperilakuan organisasional yang amat kompleks, struktur organisasi dan gaya kepemimpinan yang tidak kompatibel, integrasi dan transfer teknologi ysng tidak tepat, transformasi budaya yang tidak tepat atau kurang berfungsi, dan konsolidasi internal dan pelatihan yang tidak memadai. Sementara faktor-faktor dari lingkungan eksternal mencakup pemilihan timing merger \& akuisisi yang tidak tepat sehingga menimbulkan resistensi atau tidak ada respon dari pasar, perubahan peraturan dan kebijakan pemerintah, dan ketidakpastian perubahan kondisi ekonomi dan politik yang tidak kondusif.

Untuk mencapai hasil akhir merger \& akuisisi yang memuaskan dan berkelanjutan, maka desain organisasional (corporate strategy) terhadap faktor-faktor tersebut menjadi sangat penting untuk diperhatikan oleh tim task force merger \& akuisisi, CEO dan manajemen dari korporat baru hasil merger \& akuisisi. Hal ini penting karena berdasarkan hasil analisis yang komprehensif dari Bowman et al. (2001), corporate strategy bermakna/bernilai bagi profitabilitas perusahaan. Secara keseluruhan, Bowman et al. (2001) menemukan bahwa efek korporat adalah substansial dan corporate management dan corporate strategy berkontribusi pada corporate effects. Secara teoritis, Mintzberg et al. (1998) menyatakan bahwa strategi korporat berperan menentukan arah dan fokus organisasi, memberikan makna dan pemahaman yang komprehensif tentang organisasi kepada seluruh anggota organisasi, dan memberikan konsistensi serta mengurangi ambigiutas.

Dari hasil review terhadap sejumlah literatur (Harper \& Cormeraie 1995; Covin et al. 1997; Marks 1997; Buono 1997; Hoare \& Cartwright 1997; Rinserberg 1997; Lako 1997, 1998; Nikandrou et al. 2000; Adams \& Neely 2000; Appelbaum 2000; Bijlsma-Frankema 2001), maka paling sedikit ada lima aspek yang diperhatikan dicermati dan disiasati dalam desain dan implementasi organisasional terhadap proses merger \& akuisisi.

Pertama, pihak-pihak yang melakukan merger perlu cermat dalam menelaah bibit, bebet dan bobot dari masing-masing entitas yang akan "dikawinkan" sehingga partner yang terpilih atau yang bergabung adalah yang terbaik. Faktor pemicu utama kegagalan merger \& akuisisi selama ini, baik di AS dan Eropa maupun di Indonesia, adalah karena proses merger sering dilakukan secara paksa tanpa memperhatikan bibit, bebet dan bobot dari masing-masing entitas yang "dikawinkan" sehingga timbul perselisihan atau percekcokan yang sulit didamaikan dan berdampak buruk pada kinerja korporat.

Kedua, masing-masing pihak yang akan "dikawinkan" perlu menentukan dan menyepakati suatu bentuk merger yang cocok. Ada tiga alternatif yang dapat dilakukan:

1. Menggabungkan dua entitas atau lebih dengan memakai nama salah satu korporat yang sudah ada. Alternatif ini dipilih apabila korporat tersebut memiliki kinerja keuangan dan kinerja manajerial lebih baik dari entitas lainnya sehinnga nama entitas diharapkan akan memiliki "brand" atau "goodwill" di mata stakeholders dan berdampak positif terhadap peningkatan market value dan value of the firm dari entitas baru hasil merger;

2. Menggabungkan dua entitas atau lebih, namun entitas yang akan bergabung tersebut menyepakati untuk memakai nama baru. Alternatif ini dapat dipilihapabila kinerja kinerja dari 
masing-masing entitas yang akan bergabung relatif kurang bagus sehingga nama entitas baru tersebut diharapkan akan menciptakan persepsi baru di mata stakeholders yang berkentingan langsung dan tidak langsung dengan keberadaan entitas baru hasil merger \& akuisisi;

3. Salah satu entitas yang memiliki size yang lebih besar, misalnya leading dalam bentuk pangsa pasar dan aset-ekuitas, menjadi korporat induk, sementara entitas-entitas lain yang lebih kecil size-nya menjadi anak perusahaan. Ini berarti bahwa entitas-entitas yang menjadi anak perusahaan perlu menyesuaikan diri dengan dengan sistem manajemen, budaya organisasi, struktur organisasi, gaya kepemimpinan, teknologi informasi dan lainnya yang telah diterapkan atau didesain oleh korporat induk. Untuk menghindari terjadinya problema organisasional yang disebabkan oleh kesenjangan komunikasi, stres dan depresi, ketegangan, dan rendahnya motivasi antar karyawan yang diakibatkan oleh perbedaan faktor-faktor kultural organisasi yang masih melekat pada masing-masing korporat, maka tim task force merger \& akuisisi dan manajemen perlu melakukan desain dan integrasi budaya organisasional dan transformasi gaya kepemimpinan organisasional (terutama transformasi ke transformational leadership) yang mampu menjadi "payung" untuk menyatukan seluruh kepentingan karyawan yang berbeda kultural ke dalam satu visi dan sinergi yang sama untuk pencapaian tujuan korporat baru hasil merger \& akusisi.

Ketiga, masing-masing korporat yang akan melakukan merger perlu menyamakan perbedaan persepsi menyangkut aspek-aspek dan masalah-masalah yang bersifat nonteknis dan menuntaskan masalah-masalah teknis manajerial dan organisasional. Kendala-kendala nonteknis, misalnya menyangkut gengsi para pemilik atau manajemen dari masing-masing korporat yang merasa malu apabila perusahaannya melakukan merger dengan korporat lain. Mereka enggan melakukan merger karena takut akan kehilangan kepemilikan, posisi dan kendali terhadap korporat baru hasil merger \& akuisisi. Sedangkan kendala-kendala teknis manajerial dan organisasional berkaitan dengan aspek: 1) belum adaptifnya budaya oragnisasi dari masingmasing korporat yang diintegrasikan sehingga menimbulkan kesejangan kultural dan komunikasi antar karyawan; 2) penilaian kembali dan penetapan harga saham dari masing-masing korporat secara adil dan proporsional jika masing-masing entitas sudah go public; 3) desain suatu grand corporate strategy dan desain struktur organisasi, sistem manajemen dan sistem kontrol manajemen untuk mendorong keberhasilan merger \& akuisisi; 4) integrasi dan transfer teknologi yang tepat guna untuk memacu ekonomisasi, produktivitas, efisiensi dan efektivitas ekonomik dan manajerial korporat; 5) penyatuan dan redefinisi terhadap misi, visi, tujuan dan sasaran bersama korporat baru; dan 6) perumusan kembali terhadap core business dan core competence korporat pasca merger.

Keempat, melakukan konsolidasi internal, membangun komitmen bersama dan melakukan pembelajaran (learning), pemberdayaan (empowerment) dan pembertumbuhan (growth) terhadap semua pelaku organisasi, baik manajemen maupun karyawan, secara berkelanjutan. Untuk itu, para CEO dan manajemen baru korporat hasil merger \& akuisisi perlu memahami banyak hal berkenaan dengan masalah-masalah dan isu-isu integrasi yang muncul dalam korporat baru, menyalurkan sumberdaya ekonomik dan mengalihkan dari kinerja yang diperlukan untuk mengelola transisi dari status pre-merger ke status post-merger; dan memahami isu-isu keperilakuan yang melekat pada karyawan yang dapat diberdayakan dan dikembangkan dalam suatu merger atau akuisisi (Marks 1997).

Kelima, mempertimbangkan ketepatan dalam pemilihan timing merger \& akuisisi. Pemilihan timing merger \& akuisisi pada saat kondisi ekonomi sedang krisis atau resesi dan kondisi lingkungan eksternal tidak kondusif dapat menjadi bumerang bagi korporat baru hasil merger \& akuisisi karena adanya resistensi dari pasar atau tidak adanya tanggapan positif dari pasar. Selain itu, jika pasar mengetahui bahwa proses persiapan dan konsolidasi merger tidak dilakukan secara matang, entitas yang melakukan merger \& akuisisi kurang memiliki sinergi yang tinggi, dan kendala-kendala organisasional belum dapat diintegrasikan secara baik, maka 
pengumuman merger \& akuisisi akan dipandang sebagai suatu "bad news" bagi pasar saham. Para konsumen dan external stakeholders lainnya juga akan dihadapkan pada berbagai kebingungan dan keresahan yang tinggi terhadap relasi baru mereka dengan korporat baru hasil merger \& akuisisi.

Karena itu, timing merger \& akuisisi yang tepat adalah ketika kondisi lingkungan eksternal cukup kondusif dan aspek-aspek seperti telah disebutkan pada poin pertama hingga keempat dicermati dan dilaksanakan tepat. Dengan kata lain, coalignment antara strategi merger \& akuisisi dengan faktor-faktor internal dan eksternal organisasi menjadi salah satu kunci keberhasilan suatu merger \& akuisisi. Hasil review yang penulis lakukan terhadap sejumlah proyek merger \& akuisisi di Indonesia sejak dekade 1970an hingga awal 200an menunjukkan bahwa tingginya tingkat kegagalan merger \& akuisisi terutama disebabkan oleh kelima faktor tersebut di atas (Lako 1997a, 1997b, 1998a dan 1998b).

\section{SIMPULAN}

Sejumlah analisis literatur dan hasil studi empiris telah memdokumentasikan bahwa gelombang merger \& akuisisi (M\&A) yang terjadi di Amerika Serikat, Canada dan negara-negara Eropa pada dekade 1980an hingga awal dekade 2000an tidak selalu memberikan hasil akhir yang memuaskan untuk peningkatan the value of the firms dan stakeholders wealth. Bahkan, tingkat kegagalan merger \& akuisisi jauh lebih besar daripada tingkat kesuksesannya, yaitu berkisar antara 50 - 80 persen. Namun sejauh yang penulis telusuri, investigasi secara komprehensif dan mendalam terhadap faktor-faktor pemicu terjadinya gelombang merger \& akuisisi dan faktor-faktor pemicu kesuksesan-kegagalan merger \& akuisisi tersebut masih sangat sedikit dan lebih bersifat parsial.

Tulisan ini merupakan suatu hasil literature review yang menginvestigasi kontribusi corporate strategy dalam kesuksesan-kegagalan merger \& akuisisi di Amerika dan Eropa selama tiga dekade yaitu 1980an - 2000an. Hasil review menunjukkan bahwa faktor-faktor pemotivasi terjadinya gelombang merger \& akuisisi sangat bervariasi. Secara umum, faktor pemotivasinya dapat dibedakan menjadi dua yaitu untuk meningkatkan nilai pasar ekuitas yang dimiliki oleh para pemegang saham dan CEO yang ada, dan 2) untuk meningkatkan kesejahteraan manajemen yang ada. Secara khsusus, motif dilakukan merger \& akuisisi ntara lain adalah (1) untuk pertumbuhan internal dan eksternal bisnis; (2) untuk mendapatkan sinergi bisnis berupa operating sinergy berupa economies of scale dan economies of scope yang secara ekonomis dapat meningkatkan penerimaan dan mengurangi kos; dan financing sinergy yaitu merujuk pada dampak merger \& akuisisi terhadap cost of capital untuk partner merger atau pengakuisisi; (3) untuk meningkatkan market share dan market power korporat terhadap pesaing, dan memperkuat buyerseller relationship; (4) untuk mendapatkan tax benefits; (5) untuk memperbaiki atau meningkatkan efektivitas ekonomi dan manajerial, (6) memperkuat insentif, (7) mencapai business fit yang lebih baik dan mempertajam fokus manajemen, dan (8) masih banyak lagi.

Sementara faktor pemicu kegagalan merger \& akuisisi adalah 1) adanya ambigiu dan kesenjangan komunikasi lintas-kultural antar manajemen dan para karyawan; 2) pengelolaan terhadap integrasi kultural dan proses perubahan kultural yang tidak tepat dan tidak memadai; 3) gaya kepemimpinan baru yang tidak kondusif dan transformasional sehingga tidak kompatibel dengan iklim korporat baru; 4) ketidakcukupan dalam melakukan perencanaan dan konsolidasi internal serta pelatihan yang tidak memadai terhadap karyawan yang berbeda kultural; 5) ketidaktepatan dalam menganatomi perilaku faktor-faktor organisasional dan processes throughout sebelum dan sesudah merger \& akuisisi; dan 6) pemilihan timing dan partner yang tidak tepat.

Untuk itu, maka desain organisasional terhadap corporate strategy untuk merger \& akuisisi menjadi sangat penting untuk dicermati dan disiasati. Paling sedikit ada lima aspek yang dicermati dan disiasati: 
1. Pihak-pihak yang melakukan merger perlu cermat dalam menelaah bibit, bebet dan bobot dari masing-masing entitas yang akan "dikawinkan" sehingga partner yang terpilih atau yang bergabung adalah yang terbaik;

2. Masing-masing pihak yang akan melakukan merger \& akuisisi perlu menentukan dan menyepakati suatu bentuk merger yang cocok. Ada tiga alternatif yang dapat dilakukan yaitu: a) menggabungkan dua entitas atau lebih dengan memakai nama salah satu korporat yang sudah ada, b) menggabungkan dua entitas atau lebih, namun entitas yang akan bergabung tersebut menyepakati untuk memakai nama baru, dan c) salah satu entitas yang memiliki size yang lebih besar menjadi korporat induk, sementara entitas-entitas lain yang lebih kecil sizenya menjadi anak perusahaan;

3. Masing-masing korporat yang melakukan merger perlu menyamakan perbedaan persepsi menyangkut aspek-aspek dan masalah-masalah yang bersifat nonteknis dan menuntaskan masalah-masalah teknis manajerial dan organisasional;

4. Melakukan konsolidasi internal, membangun komitmen bersama dan melakukan pembelajaran dan pemberdayaan (empowerment) terhadap semua pelaku organisasi, baik manajemen maupun karyawan, secara berkelanjutan;

5. Mempertimbangkan ketepatan dalam pemilihan timing merger \& akuisisi.

\section{DAFTAR PUSTAKA}

Adams, C. \& A. Neely. (2000). "The Perdormance Prism to Boost M\&A Success". Measuring Business Excellence. Vol 4 No.3 pp. 19-23.

Appelbaum, A.H., J. Gandel, B.T. Shapiro, P. Bellsle \& E. Hoeven. (2000). "Anatomy of a Merger. Behavior of Organizational Factors and Processes throughout the pre- during-post-Merger Part 1 \& 2". Management Decision. Vol 38 No 10 pp. $649-661$ \& 674-684

Asquith, P. (1983). "Merger Bids, Uncertainty and Stockholder Returns". Journal of Financial Economics. Vol 11 No.1 (April) pp. 51-83.

Ahuja, G., \& R. Katila. (2001)."Technological Acquisitions and the Innovation Performance of Acquiring Firms: A Longitudinal Study". Strategic Management Journal. Vol 22 pp. 197220

Baker, H.K., T.o. Miller \& B.J. Ramsperger. (1983). "A typology of Merger Motives". Akron Business and Economic Review. (Winter) pp. 24-29.

Bieshaar, H., J. Knight \& A. van Wassenaer. (2001). "Deals that Create Value". The McKinsey Quarterly. No.1 pp. 65-73.

Bijlsma-Frankema, K. (2001). "On Managing Cultural Integration and Cultural Change Process in Mergers and Acquisitions". Journal of European Industrial Training. Vol 2 No. 4 pp. $192-$ 207

Bowman, E.H., \& C.E. Helfat. (2001). "Does Corporate Strategy Matter?". Strategic Management Journal. Vol 22 pp. 1-23

Bradley, M., A. Desai \& E.H. Kim. (1983). "The Rationale Behaind Interfirm tender Offers: Information or Synergy". Journal of Financial Economics. Vol 11 No.1 pp. 183-206. 
Buono, A.F. (1997). "Technology Transfer throuh Acquisition. Management Decision. Vol. 35 No.3 pp. 194-204.

Chartterjee, S. (1992). "Sources of Value in Takeovers: Synergy of Restructuring-Implications for target and Bidder Firms". Strategic Management Journal. Vol 13 pp. 267-286

\& M. Lubatkin. (1990). "Corporate Merger, Stakeholder Diversification, and Changes in Systematic Risk". Strategic Management Journal. Vol 11 pp. 255-267

Covin, T,J., T.A. Kolenko, K.W. Sightler \& R.K. Tudor. (1997). "Leadership Style and Post-Merger Satisfaction". Journal of Management Development. Vol 16 No.1 pp. 22-33

Foster, G. (1986). Financial Statement Analysis. Second Edition. Prentice-Hall International

Frank, G. (1990). "Mergers and Acquisitions: Competitive Advantages ans Cultural Fit". European Management Journal. Vol 8 No.1 (March).

Gaughan, P.A. (1999). Mergers, Acquisitions, and Corporate Restructurings. John Wiley \& Sons, Inc. New York.

Goldberg, S.R. \& J.H. Godwin. (2001). "Your Merger: Will it Really Add Value?" The Journal of Corporate Accounting \& Finance. January/February pp. 35- 27

Goold, M., \& K. Luchs. Why Diversify? Four Decades of Management Thingking. Academy of Management pp. 7-25

Gopinath, C. \& T.E. Becker. (2000). "Communication, Procedural Justice, and Employee Attitudes: Relationships under Conditions of Divestiture". Journal of Management. Vol. 26 No.1 pp. 63-85.

Hackett, M.C. (1996). "Are there Alternatives to Merger?". Health Manpower Management. Vol. 22 No.5 pp. 5-12

Harper, J. \& S. Cormeraie. (1995). "Mergers, Marriages and After: How Can Training Help?" Journal of European Training. Vol 19 No 1 pp. 24-29

Hayward, M.L.A., \& D.C. Hambrick. (1995). Explaining Premiums Paid for Larger Acquisitions: Evidence of CEO Hubris. Working Paper.

Hill, C.W.L. (1994). Diversification and Economic Performance : Bringing Structure and Corporate Management Back into Picture. Dalam Rumelt, P.C., D.E. Schemdel \& D.J. Teece (Eds.). Fundamental Issues in Strategy. pp. 297-322

Hoare, S.C. (1997). "The Human Aspects of Demerger: A New Agenda for Research". Leadership \& Organization Development Journal. Vol 18 No.4 pp. 194-2000

Johnson, H. (1995). Bank Mergers, Acquisitions and Strategic Alliances. Richard D. Irwin. New York. 
KINERJA, Volume 8, No. 1, Th. 2004: Hal. 70-81

Krug, J.A. \& W.H. Hegarty. (2001). "Predicting Who Stays and Leaves After an Axquisition: A Study of Top Managers in Multinational firms". Strategic Management Journal. Vol 22 pp.185-196

Kwansa, F.A. (1994). "Acquisitions, Shareholder Wealth and the Lodging Sector: 1980-1990". International Journal of Contemporary Hospitality Management. Vol 6 No 6 pp. 16-20

Lako, A. (1997a). Risiko Merger dan Strategi Antisipasi. Bisnis Indonesia. 23 Desember.

. (1997b). Analisis Rencana Merger Bank BUMN: kebijakan Yang Mengejutkan. Bank \& Manajemen. Juli-Agustus.

. (1998a). Bayang-Bayang Kegagalan Merger. Manajemen \& Usahawan Indonesia. No. 8. Agustus.

(1998b). Impian Merger Tak Pasti. KONTAN. No.4. 18 Oktober 1998

Marks, M.L. (1997). "Consulting in Mergers and Acquisitions: Interventions Spawed by Recent Trends". Journal of Organizational Change Management. Vol 10. No. 3. 267-279 (1999). "Surviving a Merger". Electric Perspective. Vol 24 No 6 pp. 26-35

Michael, A., \& I. Shaked. (1984). "Does Business Diversification Affect Performance?" Financial Management. Winter. pp. 18-24

Mintzberg, H., B. Ahlstrand \& J. Lampel. (1998). Strategy Safary: A guide Tour Through the Wilds of Strategic Management. The Free Press. New York.

Morck, R., A. Shleifer \& R. Vishny. (1990). "Do Managerial Objectives Drive Bad Acquisitions?". Journal of Finance. Vol. 45 No.1pp. 31-48

Nail, L.A., W.L. Megginson \& C. Maquieira. (2001). How Stock-SWAP Mergers Affect Shareholder (ans Bondholder) Wealth: More Evidence of the Value of Corporate "Focus". Dalam Chew, Jr D. H. (Ed.), "The New Corporate Finance: Where Theory Meets Practice". Third Edition. McGraw-Hill//rwin. New York. pp 544-555

Nguyen, T.H. \& A. Seror. (1990). "Diversification Strategy and Performance in Canadian Manufacturing Firms". Strategic Management Journal. Vol 11 pp. 411-418

Nikandrou, I., N. Papalexandris \& D. Boutrantas. (2000). "Gaining Employee Trust after Acquisition: Implication for Managerial Action". Employee Relations. Vol. 22 No. 4 pp. 334355

Post, J.E., W.C. Federick, A.T. Lawrence \& J. Weber. (1996). Business and Society: Corporate Strategy, Public Policy, and Ethics. Eight Edition. McGraw-Hill, Inc.

Risberg, A. (1997). "Ambiguity and Communication in Cross-Cultural Acquisitions: Towards a Conceptual Framework". Leadership \& Organization Development Journal. Vol 18. No.5 pp. $257-266$ 
Shleifer, A. \& R.W. Vishny. (1994). Takeovers in the 1960s and the 1980s: Evidence and Implications. Dalam Rumelt, P.C., D.E. Schemdel \& D.J. Teece (Eds.). Fundamental Issues in Strategy. pp.403-422

Stewart III, G.B., D.M. Glassman, \& S. Stewart \& Co. (2001). The Motives and Methods of Corporate Restructuring. Dalam Chew, Jr D. H. (Ed.), "The New Corporate Finance: Where Theory Meets Practice". Third Edition. McGraw-Hill/Irwin. New York. pp 529-543

Tetenbaum, T.J. (1999)." Beating the Odds of Merger \& Acquisition Failure.: Seven Key Practices that Improve the Chance for Expected Integration and Synergies". Organizational Dynamics. Vol. 28 No.2 pp. 22-36

Varaiya, N.P. (1989). "Winners Curse Hypothesis and Corporate Takeovers". Managerial nd Decision Economics. Vol. 9. 109-125

Whalen, P.T. (2000). Study to Explore How Communication Drive Merger Success. Working Paper. 